\section{Å selge sykdom}

I oktober 2013 publiserte Abramson og medarbeidere en studie i BMJ som viste at statiner gitt til personer med lav risiko for kardiovaskulær sykdom verken reduserte totaldødelighet eller risiko for alvorlig sykdom, mens de fant om lag $18 \%$ risiko for bivirkninger (1). På dette grunnlaget mente de at det ville være feil å utvide indikasjonsområdet for statiner, slik en Cochrane-rapport nylig hadde anbefalt (2). I etterkant av publiseringen var det en faglig diskusjon særlig rundt beregninger av bivirkningsfrekvensen, noe som førte til at forfatterne korrigerte tallet. Hovedfunnet - ingen effekt på totaldødelighet, og dermed mer risiko enn effekt - ble stående.

Så langt var alt som normalt: En artikkel kom inn til et tidsskrift, den ble kvalitetssikret redaksjonelt og av eksterne fagvurderere, publisert, kommentert og debattert i full åpenhet. Men dette er ikke hele historien: I desember 2013 oppsøkte Rory Collins, professor i medisin og epidemiologi ved universitetet i Oxford, sjefredaktør Fiona Godlee i BMJ og forlangte at artikkelen skulle trekkes tilbake. Da dette ikke førte frem, gikk han til britiske medier der han anklaget BMJ for å drive med en skrekkpropaganda som ville ta livet av svært mange mennesker (3). Da heller ikke dette førte frem, sendte han et konfidensielt brev til Godlee. Han avslo gjentatte ganger å delta i den faglige debatten på vanlig vis, nemlig åpent i BMJs spalter (4).

I november 2013 publiserte Vigen og medarbeidere en studie i JAMA som viste at testosteronbehandling av menn som gjennomgikk koronar angiografi var assosiert med økt risiko for uheldige utfall (5). I etterkant av publiseringen var det en faglig diskusjon rundt beregningene. Forfatterne korrigerte da noen tall og utsagn. Hovedfunnet - økt risiko for uheldige utfall for menn med uklar gevinst av testosteronbehandling - ble stående.

Men heller ikke her er dette hele historien: I mars 2014 bestemte en gruppe leger som var uenige i konklusjonene i JAMA-artikkelen seg for å danne en ad hoc-gruppe kalt Androgen Study Group. Gruppen sendte et brev til sjefredaktør Howard Bauchner med en sterk anmodning om å trekke tilbake artikkelen. Istedenfor å argumentere på vanlig vitenskapelig vis, åpent og i tidsskriftets spalter, spredte de brevet vidt og bredt $i$ amerikanske medier. Abraham Morgentaler, leder av gruppen, uttalte i en pressemelding (6): «Brevet er en fullstendig tilbakevisning av den falske informasjonen publisert i JAMA. Informasjonen har skadet folkehelse, forvrengt medisinsk vitenskap og brutt tilliten mellom medisinske tidsskrifter og forbrukeren.» Per dags dato (20.5. 2014) har ikke sjefredaktøren i JAMA noen planer om å trekke artikkelen tilbake.

Hva er felles for disse historiene? Det mest iøynefallende er de økonomiske interessene. Kolesterolsenkende behandling med statiner var i mange år en nesten sammenhengende suksesshistorie både medisinsk og økonomisk. I 2011 ble det omsatt statiner for om lag
120 milliarder kroner på verdensbasis. Men kombinasjonen av opphørende patenter og økende antall rapporter om mulige bivirkninger truer naturligvis omsetningen. En måte å holde omsetningen oppe på er å utvide indikasjonsområdet - for eksempel til å gjelde reduksjon av kolestrolnivåer hos symptomfrie voksne. En studie som den Abramson og medarbeidere publiserte kan da ha en potensielt svært uheldig effekt på omsetningen. Og Rory Collins rolle? I tillegg til å være professor er han også leder av Cholesterol Treatment Trialists' Collaboration, en gruppe som bl.a. sammenfatter og reanalyserer studier av kolesterolsenkende medikamenter - de fleste finansiert av legemiddelindustrien.

Historien om testosteronbehandling er en litt annen. Mens det er godt dokumentert at forhøyede kolesterolnivåer er uheldig og at en reduksjon er positivt, så er det høyst uklart om «for lavt» testosteronnivå faktisk er en sykdom og hvilken effekt behandling har. Selvsagt skal mannlig hypogonadisme behandles, men hvor går grensen mellom normal aldring og patologi? Det er lett å se at en liten justering åpner opp et stort marked, slik Schwartz \& Woloshin så presist beskriver i «how to sell a disease» (7). Og Abraham Morgentalers rolle? Han er leder av Men's Health Boston som har som hovedoppgave «å hjelpe det medisinske miljø og befolkningen til å forstå hvordan man trygt kan behandle menn som har testosteronmangel». Han får støtte fra bl.a. AbbVie som markedsfører AndroGel (Testogel i Europa) - den mest brukte testosteronbehandling i USA.

Påfallende med disse historiene er også maktmidlene som brukes mot redaktørene. I stedet for å argumentere åpent og faglig forsøker kolleger gjennom bakveier å få fjernet artikler de misliker ved å bruke hersketeknikker som indirekte trusler, sjikane og latterliggjøring. Det bør ikke lykkes. Vi har store nok problemer i medisinen når så godt som alle kliniske studier av legemidler og medisinsk utstyr finansieres av det selskapet som også vil ha direkte interesse av at det brukes. Da bør forsøk på å etterprøve resultatene oppmuntres, ikke bli forsøkt stoppet.

\section{Litteratur}

1. Abramson JD, Rosenberg HG, Jewell N et al. Should people at low risk of cardiovascular disease take a statin? BMJ 2013; 347: f6123

2. Taylor F, Huffman MD, Macedo AF et al. Statins for the primary prevention of cardiovascular disease. Cochrane Database Syst Rev 2013; 1: CD004816.

3. Boseley S. Doctors' fears over statins may cost lives, says top medical researcher. The Guardian 21.3.2014

4. Godlee F. Adverse effects of statins. BMJ 2014; 348: g3306.

5. Vigen R, O'Donnell Cl, Barón AE et al. Association of testosterone therapy with mortality, myocardial infarction, and stroke in men with low testosterone levels. JAMA 2013; 310: 1829-36.

6. Twenty-five medical societies join Androgen Study Group to petition JAMA to retract misleading testosterone study. www.prnewswire.com/news-releases/ twenty-five-medical-societies-join-androgen-study-group-to-petition-jama-toretract-misleading-testosterone-study-254707661.html (20.5.2014).

7. Schwartz LM, Woloshin S. Low «T» as in «template»: how to sell disease. JAMA Intern Med 2013; 173: 1460-2. 